\title{
Super Antibiotics, Part II. Hyperforin, Mass Spectroscopy (MS) and Gas Chromatography-Mass Spectrometry (GC-MS), Evidence of Permeability of the Blood-Testis Barrier (BTB) and the Blood-Brain Barrier (BBB) to Hyperforin
}

\author{
Ilia Brondz \\ Norwegian Drug Control and Drug Discovery Institute (NDCDDI), Ski, Norway \\ Email: ilia.brondz@gmail.com
}

How to cite this paper: Brondz, I. (2016) Super Antibiotics, Part II. Hyperforin, Mass Spectroscopy (MS) and Gas Chromatography-Mass Spectrometry (GC-MS), Evidence of Permeability of the Blood-Testis Barrier (BTB) and the Blood-Brain Barrier (BBB) to Hyperforin. International Journal of Analytical Mass Spectrometry and Chromatography, 4, 66-73.

http://dx.doi.org/10.4236/ijamsc.2016.44007

Received: October 27, 2016

Accepted: December 9, 2016

Published: December 12, 2016

Copyright $(92016$ by author and Scientific Research Publishing Inc. This work is licensed under the Creative Commons Attribution International License (CC BY 4.0).

http://creativecommons.org/licenses/by/4.0/ c) (i) Open Access

\begin{abstract}
In the first article of this series, we presented some evidence of hyperforin as an antibiotic, antiprotozoal, antiviral, anticancer, and immunomodulatory substance. In the present article, evidence of the permeability of the blood-testis barrier (BTB) and blood-brain barrier (BBB) to hyperforin and its distribution in other organs of the domestic pig (Sus scrofa domesticus) are revealed. Seven-month-old male boars with a body mass of $100 \mathrm{~kg}$ were fed a diet containing hyperforin. Organs were surgically removed under anesthesia. Organs were suitable prepared and extracted, and then analyzed using gas chromatography-mass spectrometry with supersonic molecular beams (GC-MS with SMB). The presence of hyperforin was recorded in all organs and body fluids. Special attention was paid to the evaluation of the presence of hyperforin in the brain and testes of experimental animals. The presence of hyperforin in the brain and testes of experimental animals was established by GC-MS with SMB. The results are of interest because penicillin and numerous other antibiotics cannot pass through the BTB or BBB if healthy or non-inflamed, which limits their use in patients with meningitis and gonorrhea. The findings are also of interest in cases of penicillin- and multi-antibiotic-resistant bacterial infections.
\end{abstract}

\section{Keywords}

Antibiotics, Hyperforin, Super antibiotic, Mass Spectroscopy, Gas

Chromatography-Mass Spectrometry, Blood-Testis Barrier, Blood-Brain Barrier, 


\section{Introduction}

A previous publication [1] has explained the urgent necessity for the development and introduction of a new generation of antibiotics with the ability to act against methicillin-resistant Staphylococcus aureus (MRSA) and other antibiotic-resistant microorganisms, as well as against multi-antibiotic-resistant bacteria, into medical practice. Of especially high value are antibiotics such as hyperforin that exhibit positive immunomodulatory effects. In some cases, it is a primary necessity to have a tool that passes through the BTB or BBB at all stages of infectious diseases, as well as in generalized inflammatory stages, and in such as the healing and healthy (post inflammatory) stages, to allow the total clean-up of the organ from possible remaining infectious agents and the total eradication of infection from the organs, even after the disappearance of clinical symptoms.

Previous research [2] described some microorganisms affected by hyperforin, including those that are penicillin-resistant. Subsequently, the immunomodulatory action of hyperforin was presented in [3] [4] [5] [6]. After Brondz completed a graduate degree in the pharmaceutical sciences in 1979, he performed all research on the medical use of hyperforin at a private company, Jupiter, and later at Jupiter AS (Jupiter Ltd.) because of the unscientific, unethical approach of Docent Aasen (Pharmaceutical Department, University of Oslo, Norway), who aimed to commercialize the scientific work of Brondz without his knowledge.

The presented works are based on previous research [2] [3] [4] [5] [6] and studies performed in the former Soviet Union on the pharmaceutical form of Novoimanin [7] [8] [9], which contains a considerable percentage of hyperforin. Relatively new research has also revealed additional useful properties of hyperforin, such as anticancer [10], [11], anti-inflammatory [12], and antiprotozoal/antimalarial activities [13], as well as its role as an additional tuberculosis medication [14].

The 1972 thesis of Volosovets and Resnick, entitled "Novoimanin stimulant immunogenesis", provides some clues regarding the possible effect of Novoimanin on the immune system of experimental animals. However, Novoimanin is a complex mixture of a large number of natural products. It was therefore necessary to identify the exact substance that had an impact on the immune system: hyperforin [3] [4] [5] [6].

\section{Mass Spectral Elucidation of the Structure of Hyperforin}

The study of hyperforin was started in the former Soviet Union. Because of the thermolability of hyperforin, it was difficult to record its gram mol (molecular weight) by MS using electron impact (EI). In the former Soviet Union the gram mol of hyperforin was elucidated by element analysis. In Norway in 1978, we experienced the same problems. To correct this, the fraction containing hyperforin was used for biological detec- 
tion via element analysis and MS with EI, even though MS with EI did not give conclusive results. To obtain conclusive results for $\mathrm{M}^{+}$and support the fragmentation of the hyperforin molecule as an isoprene-contacting substance, MS with chemical ionization by $\mathrm{NH}_{3}$ was performed [2].

The results supported the element analysis of the gram mol $(536 \mathrm{gr} / \mathrm{mol})$ of hyperforin as $\mathrm{M}^{+} \mathrm{m} / z 537$ and demonstrated the presence of isoprene chains by fragmentation [2] (Figure 1).

Subsequently, in all MS investigations, $\mathrm{M}^{+} \mathrm{m} / z 537$ was used as a reference point and the specificity of molecular fragmentation as $m / z 55, m / z 56, m / z 67, m / z 68, m / z 69$, and $m / z$ 83, as well as the presence of a characteristic ion with $m / z 277, \mathrm{~m} / z 401, \mathrm{~m} / z$ $411, \mathrm{~m} / \mathrm{z} 413$ and $\mathrm{m} / \mathrm{z} 469$ used as a support.

\section{Materials and Methods}

\subsection{Biological Materials}

Hyperforin was donated by Jupiter Ltd., Norway. Sample was analyzed by MS for authenticity.

Three domestic pigs (Sus scrofa domesticus) were used in the experiments. Male boars aged 7 - 8 months with body masses of 100 - $110 \mathrm{~kg}$ were fed a diet containing hyperforin (10 mg/kg of body weight) for 14 days, three times/24 h. Several organs (including the brain, testis, heart, lungs, kidneys, liver, and blood) were surgically removed under anesthesia, and after suitable preparation, extraction, and clean-up, were analyzed by gas chromatography-mass spectrometry with supersonic molecular beams (GC-MS with SMB). Extracts were also kindly provided by Jupiter Ltd., Norway.

\subsection{Gas chromatography-Mass Spectrometry with Supersonic Molecular Beams (GC-MS with SMB) of Sus scrofa domesticus Testes Extracts}

One milligram of vacuum-frozen dry extract from testes was dissolved immediately before the GC-MS analysis in $1 \mathrm{~mL}$ of chromatography-grade $n$-hexane (quality for liquid chromatography LiChrosolv ${ }^{\circledR}$ (Merck Millipore)), which was purchased from Sigma-Aldrich, Norway.

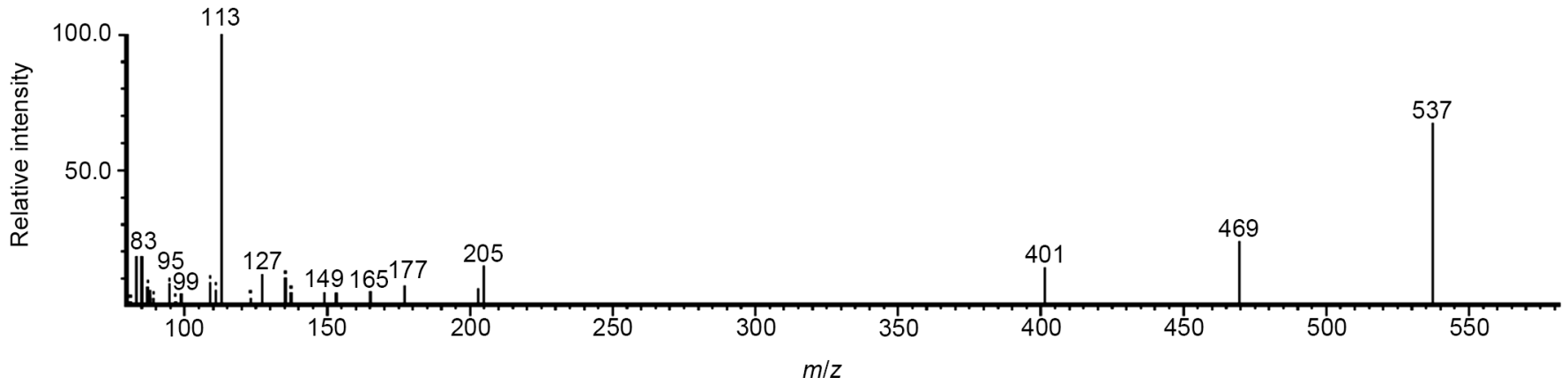

Figure 1. The mass spectrum of hyperforin shows an $\mathrm{M}^{+}$of $\mathrm{m} / z 537$, which implies that the gram/mol should be 536 . The details are given in $[2]$. 
The experimental GC-MS with SMB based on a Varian 1200 GC-MS system was performed as described in [15] [16]. Separation of the compounds was carried out using a VF-5HT column (0.25 mm I.D., $0.1 \mu \mathrm{m}$ film thickness, and $4 \mathrm{~m}$ length; Varian, Middleburg, The Netherlands). Reduction of the column's length was performed in the laboratory. The helium column flow rate was $16 \mathrm{~mL} / \mathrm{min}$. One $\mu \mathrm{L}$ of the extract in $n$-hexane at an approximate concentration of $100 \mathrm{ppm}$ was injected with a split ratio of 10:1 using the Varian 1079 injector at $240^{\circ} \mathrm{C}$. The GC oven was programmed from $120^{\circ} \mathrm{C}-280^{\circ} \mathrm{C}$ at $20^{\circ} \mathrm{C} / \mathrm{min}$, and the drug hyperforin was eluted at about $5.69 \mathrm{~min}$ without any degradation, because of the use of a short column and a high column flow rate [17] [18]. Ion source degradation was prevented using a contact-free, fly-through EI ion source [17] [19]. The separation and detection of hyperforin in the mixture are shown as a TIC chromatogram in Figure 2.

\section{Results and Discussion}

The GC-MS analyses shown in Figure 2 demonstrated the presence of hyperforin in the testes of healthy animals, which had been administered hyperforin through food. The presence of hyperforin was recorded in the brain and other organs such as the heart, lungs, kidneys, liver, and blood. The presence of hyperforin in the testis and brain of Sus scrofa domesticus suggests that the drug can pass through a healthy BTB and BBB. Because Sus scrofa domesticus serves as a physiological and pharmacological model in many medical experiments [20] [21] [22] [23] and has been accepted as a good approximation to physiological and pharmacological processes in humans, based on the results described above, it is possible to propose that hyperforin passes freely through the BTB and BBB in humans. The presence of hyperforin was recorded in the kidney, which is also important in cases of venereal illnesses such as gonorrhea and syphilis.

Hyperforin was recorded in the lungs, which is advantageous regarding its use in patients with pneumonia and tuberculosis [14]. In the past year, a rise in the number of malaria cases was observed in India, and the reappearance of malaria in Southern Europe was reported. In this regard, it is important to develop an additional tool to fight malaria [13].

\section{Conclusions}

The qualitative presence of hyperforin in the testes and brain, and in other organs of Sus scrofa domesticus was studied by GC-MS with SMB. Despite the observation that the peak with a retention time $\left(\mathrm{R}_{\mathrm{t}}\right)$ between 5.6 and $5.8 \mathrm{~min}$ also contained other lipophilic molecules in the background, the presence of hyperforin in this peak was undisputable. $\mathrm{M}^{+} \mathrm{m} / z 537$ was recorded, and fragments from isoprenoid chains were observed as $m / z 55, m / z 56, m / z 67, m / z 68, m / z 69$, and $m / z 83$, as well as the presence of a characteristic ion with $\mathrm{m} / z 277, \mathrm{~m} / z 411, \mathrm{~m} / z 413$ and $\mathrm{m} / z$ 469. The standard hyperforin had the same $\mathrm{R}_{\mathrm{t}}$ (chromatogram not shown) and characteristic $\mathrm{M}^{+} \mathrm{m} / z 537$ and the characteristic series of fragment ions with $m / z 55, m / z 56, m / z 67, m / z 68, m / z 69$, $m / z$ 83, and with $m / z 277, m / z 401, m / z 411, m / z 413$ and $m / z 469$ [24] [25] [26]. 

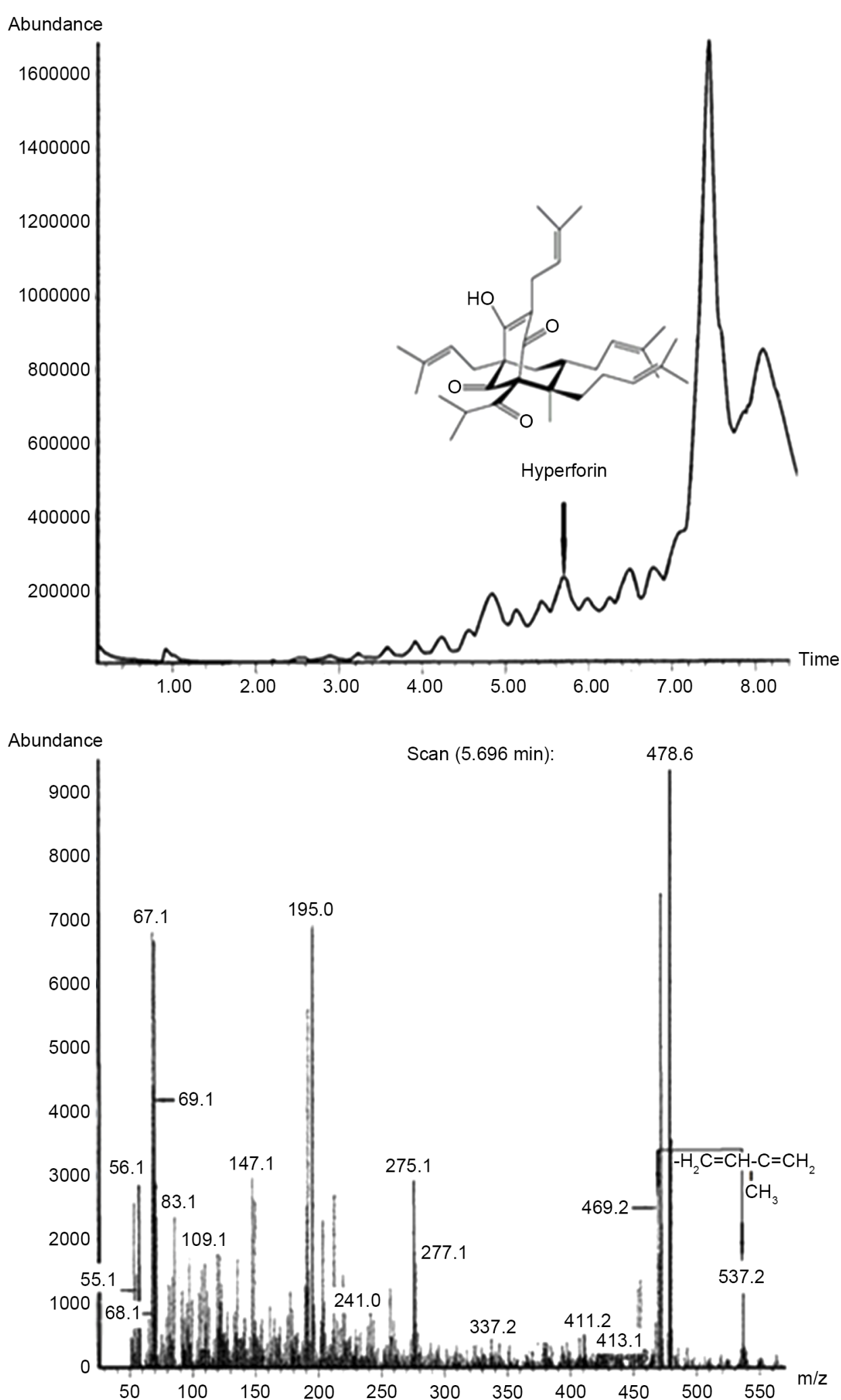

Figure 2. The upper trail is the TIC of MS of $1 \mu \mathrm{L}$ of the Sus scrofa domesticus testis extract in $n$-hexane. The peak containing hyperforin appears between 5.6 and $5.8 \mathrm{~min}$, at $5.696 \mathrm{~min}$. The lower trail is the mass spectrum taken at $5.696 \mathrm{~min}$. 
However, the quantitative presence of hyperforin in different organs and body fluids can be analyzed most suitably via supercritical fluid chromatography (SFC) and supercritical fluid chromatography-mass spectrometry (SFC-MS), because these can be performed at low temperature and by pre-isolation of the peak containing hyperforin, followed by re-chromatography or two-dimensional chromatography. The advantages of using SFC, SFC-MS compared with other chromatographic methods are presented in [27] [28] [29] [30]. There is no doubt that hyperforin passes through the BTB and BBB, and its antibacterial action against $N$. meningitidis and $N$. gonorrheae is clear. Based on its multifunctionality, hyperforin could become a useful tool in the struggle against a broad spectrum of inflammatory, infectious, and cancerous diseases. It could also become a supporting medication in cases of tuberculosis and malaria. The presence of hyperforin was recorded in the testis, brain, hart, kidney, lungs, skin, and blood of Sus scrofa domesticus after administration through the diet.

\section{Acknowledgements}

The author thanks Jupiter AS for the donation of standard-quality hyperforin and biological (tissue) samples. The author also thanks Prof. A. Amirav, Laboratory of Analytical Instruments Development, School of Chemistry, Tel Aviv University, Tel Aviv 69978, Israel for technical help with GC-MS with SMB.

\section{References}

[1] Brondz, I. (2016) Super Antibiotics, Part I. Hyperforin. Voice of the Publisher, 2. (In Print)

[2] Brondz, I. (1979) In: Antibiotikumet "Hyperforin" og andre innholdsstoffer i drogen Hypricum perforatum L. Thesis (Cand. Pharm.), University of Oslo, Oslo. (In Norwegian)

[3] Brondz, I. (1986) Lecture Entitled "The Influence of Hyperforin on Phagocytosis of E. coli by Human Polymorphonuclear Neutrophils in Vitro". Symposium "Norlændskainfektionssjkdomar”, Vårmøteti Sundsvall, 14-15 Maj 1986, Sweden.

https://www.researchgate.net/publication/233795016 The influence of hyperforin on ph agocytosis of Ecoli by human polymorphonuclear neutrophils in vitro

[4] Brondz, I. (1987) Influence of Hyperforin upon Phagocytic Functions in Human Polymorphonuclear Leucocytes. 4th International Conference on Chemistry and Biotechnology of Biological Active Natural Products, Budapest, 10-14 August 1987, Abstr. B-15, 119.

[5] Brondz, I. (2012) Enhancement of the Immunity in AIDS and Other Immunocompromised Patients by Hyperforin an Antibiotic from Hypericum perforatum L. 2nd ARIP European Conference on Antimicrobial Resistance \& Infection Prevention, Vilnius, 4-5 October 2012, 12, 60. In: Oficialus Lietuvos Bendrosios Praktikos Gydytojų Kolegijos Leidinys, No. 7, 1392-3218.

[6] Brondz, I. and Brondz, A. (2012) Recent Enhancement of the Immunity in AIDS and Other Immunocompromised Patients by Hyperforin an Antibiotic from Hypericum perforatum L. (in Vitro Model) Part I. Journal of Biophysical Chemistry, 3, 304-310. https://doi.org/10.4236/jbpc.2012.34037

[7] Volosovets, P.S. (1964) Microflora of suppurative wounds and the quantitative changes of the microflora due to the effect of treatment with amanine and novoimanine. Mikrobiologicheskii Zhurnal, 26, 60-65. 
[8] Volosovets, P.S. (1986) The Effect of Novoimanine on the Course of Experimental Staphylococcal Sepsis. Mikrobiologicheskii Zhurnal, 48, 60-64.

[9] Derbentseva, N.A. Volosovets, P.S. and Garagulya, A.D. (1970) Distribution of Novoimanin in Albino Rats after Administration by Various Means. Antibiotiki (Moscow), 15, 716-718.

[10] Donà, M., Dell'Aica, I., Pezzato, E., Sartor, L., Calabrese, F., Della Barbera, M., DonellaDeana, A., Appendino, G., Borsarini, A., Caniato, R. and Garbisa, S. (2004) Hyperforin Inhibits Cancer Invasion and Metastasis. Cancer Research, 64, 6225-6232. https://doi.org/10.1158/0008-5472.CAN-04-0280

[11] Sun, F., Liu, J.Y., He, F., Liu, Z., Wang, R., Wang, D.M., Wang, Y.F. and Yang, D.P. (2011) In-Vitro Antitumor Activity Evaluation of Hyperforin Derivatives. Journal of Asian Natural Products Research, 13, 688-699. https://doi.org/10.1080/10286020.2011.584532

[12] Koeberle, A., Rossi, A., Bauer, J., Dehm, F., Luisella Verotta, L., Northoff, H., Sautebin, L. and Werz, O. (2011) Hyperforin, an Anti-Inflammatory Constituent from St. John's Wort, Inhibits Microsomal Prostaglandin $\mathrm{E}_{2}$ Synthase-1 and Suppresses Prostaglandin E2 Formation in Vivo. Frontiers in Pharmacology, 2, 7. https://doi.org/10.3389/fphar.2011.00007

[13] Verotta, L., Appendino, G., Bombardelli, E. and Brun, R. (2007) In Vitro Antimalarial Activity of Hyperforin, a Prenylated Acylphloroglucinol: A Structure-Activity Study. Bioorganic \& Medicinal Chemistry Letters, 17, 1544-1548. https://doi.org/10.1016/j.bmcl.2006.12.100

[14] Mortensen, T.W. (2010) Hypericum perforatum as an Antimycobacterial Agent and Its Implications as an Additional Tuberculosis Medication. A Thesis Submitted in Partial Fulfillment of the Requirements for the Degree of Master of Science in Biological Engineering, Utah State University, Logan.

[15] Fialkov, A.B., Steiner, U., Jones, L. and Amirav, A. (2006) Sensitivity and Noise in GC-MS: Achieving Low Limits of Detection for Difficult Analytes. International Journal of Mass Spectrometry, 251, 47-58. https://doi.org/10.1016/j.ijms.2005.12.045

[16] Amirav, A. (2008) US Patent US20080302959 A1, Pulsed Flow Modulation Gas Chromatography Mass Spectrometry with Supersonic Molecular Beams Method and Apparatus. http://www.google.es/patents/US20080302959?hl=no

[17] Brondz, I., Fialkov, A.B. and Amirav, A. (2009) Analysis of Quinocide in Unprocessed Primaquine Diphosphate and Primaquine Diphosphate Tablets Using Gas ChromatographyMass Spectrometry with Supersonic Molecular Beams. Journal of Chromatography A, 1216, 824-829. https://doi.org/10.1016/j.chroma.2008.11.043

[18] Fialkov, A.B., Gordin, A. and Amirav, A. (2003) Extending the Range of Compounds Amenable for Gas Chromatography-Mass Spectrometric Analysis. Journal of Chromatography A, 991, 217-240. https://doi.org/10.1016/S0021-9673(03)00247-4

[19] Amirav, A., Gordin, A., Poliak, M. and Fialkov, A.B. (2008) Gas Chromatography-Mass Spectrometry with Supersonic Molecular Beams. Journal of Mass Spectrometry, 43, 141163. https://doi.org/10.1002/jms.1380

[20] Štembírek, J., Kyllar, M., Putnová, I., Stehlík, L. and Buchtová, M. (2012) The Pig as an Experimental Model for Clinical Craniofacial Research. Laboratory Animals, 46, 269-279. https://doi.org/10.1258/la.2012.012062

[21] François Meurens, F., Summerfield, A., Nauwynck, H., Saif, L. and Gerdts, V. (2012) The Pig: A Model for Human Infectious Diseases. Trends in Microbiology, 20, 50-57. https://doi.org/10.1016/j.tim.2011.11.002

[22] Swindle, M.M., Makin, A., Herron, A.J., Clubb Jr., F.J. and Frazier, K.S. (2012) Swine as Models in Biomedical Research and Toxicology Testing. Veterinary Pathology, 49, 344-356. http://vet.sagepub.com/content/49/2/344.full 


\section{https://doi.org/10.1177/0300985811402846}

[23] Tanaka, H. and Kobayashi, E. (2006) Education and Research Using Experimental Pigs in a Medical School. Journal of Artificial Organs, 9, 136-143. https://doi.org/10.1007/s10047-006-0343-2

[24] Sloley, B.D., Urichuk, L.J., Ling, L., Gu, L.-D., Coutts, R.T., Pang, P.K.T. and Shan, J.J. (2000) Chemical and Pharmacological Evaluation of Hypericum perforatum Extract. Acta Pharmacologica Sinica, 21, 1145-1152.

[25] Fuzzati, N., Gabetta, B., Strepponi, I. and Villa, F. (2001) High-Performance Liquid Chromatography-Electrospray Ionization Mass Spectrometry and Multiple Mass Spectrometry Studies of Hyperforin Degradation Products. Journal of Chromatography A, 926, 187-198. https://doi.org/10.1016/S0021-9673(01)01000-7

[26] Piccinellia, A.L., Camponea, L., Piaza, F.D., Cuesta-Rubiob, O. and Rastrellia, L. (2009) Fragmentation Pathways of Polycyclic Polyisoprenylated Benzophenones and Degradation Profile of Nemorosone by Multiple-Stage Tandem Mass Spectrometry, Spectrometry. Journal of the American Society for Mass Spectrometry, 20, 1688-1698.

https://doi.org/10.1016/j.jasms.2009.05.004

[27] Brondz, I., Klein, U., Karaliova, L., Vlachos, V., Oakley, P., Leideborg, R. and Mikhalitsyn, F. (2005) Nature of the Main Contaminant in the Drug Primaquine Di-Phosphate: Comparison of HPLC and SFC Methods. 29th International Symposium on High Performance Liquid Phase Separations and Related Techniques, Stockholm, 26-30 June 2005, 12-43.

[28] Brondz, I., Høiland, K. and Lefler, J. (2007) Supercritical Fluid Chromatography of Secondary Metabolites and Multi-Analysis by Mass Spectrometry-Ultraviolet and Corona Charged Aerosol Detection. 12th Norwegian MS-Winter Meeting, Hafjell, 21-24 January 2007, 63.

[29] Brondz, I. (2012) Editorial: Yesterday, Today and Tomorrow of Supercritical Fluid Extraction and Chromatography. American Journal of Analytical Chemistry, 3, 867-869. https://doi.org/10.4236/ajac.2012.312A114

[30] Brondz, I. and Brondz, A. (2014) Review: Isomer Separation, Chiral Resolution, and Structure Elucidation Analyses Are the Future of Analytical Supercritical Fluid Chromatography-Mass Spectrometry. International Journal of Analytical Mass Spectrometry and Chromatography, 2, 15-24. https://doi.org/10.4236/ijamsc.2014.21002

\section{Submit or recommend next manuscript to SCIRP and we will provide best service for you:}

Accepting pre-submission inquiries through Email, Facebook, LinkedIn, Twitter, etc.

A wide selection of journals (inclusive of 9 subjects, more than 200 journals)

Providing 24-hour high-quality service

User-friendly online submission system

Fair and swift peer-review system

Efficient typesetting and proofreading procedure

Display of the result of downloads and visits, as well as the number of cited articles

Maximum dissemination of your research work

Submit your manuscript at: http://papersubmission.scirp.org/

Or contactijamsc@scirp.org 